Article

\title{
Feeding of a Scleractinian Coral, Goniopora columna, on Microalgae, Yeast, and Artificial Feed in Captivity
}

\author{
De-Sing Ding ${ }^{1, * \mathbb{D}}$, Wei-Ting Sun ${ }^{2}$ and Chih-Hung Pan ${ }^{2}$ \\ 1 Ph.D. Program of Aquatic Science and Technology in Industry, College of Hydrosphere Science, National \\ Kaohsiung University of Science and Technology, No. 142, Haijhuan Rd., Nanzih District, \\ Kaohsiung 811213, Taiwan \\ 2 Department and Graduate Institute of Aquaculture, National Kaohsiung University of Science and \\ Technology, No. 142, Haijhuan Rd., Nanzih District, Kaohsiung 811213, Taiwan; \\ 1051537103@nkust.edu.tw (W.-T.S.); chpan@nkust.edu.tw (C.-H.P.) \\ * Correspondence: 1041750102@nkust.edu.tw
}

check for

updates

Citation: Ding, D.-S.; Sun, W.-T.; Pan, C.-H. Feeding of a Scleractinian Coral, Goniopora columna, on Microalgae, Yeast, and Artificial Feed in Captivity. Animals 2021, 11, 3009. https:// doi.org/10.3390/ani11113009

Academic Editor: Benedetto Sicuro

Received: 3 September 2021

Accepted: 19 October 2021

Published: 20 October 2021

Publisher's Note: MDPI stays neutral with regard to jurisdictional claims in published maps and institutional affiliations.

Copyright: (c) 2021 by the authors. Licensee MDPI, Basel, Switzerland. This article is an open access article distributed under the terms and conditions of the Creative Commons Attribution (CC BY) license (https:/ / creativecommons.org/licenses/by/ $4.0 /)$.
Simple Summary: Coral aquaculture is an innovative and sustainable aquaculture industry. Coral husbandry can address ecological environment conservation needs and industrial demand for corals. Many previous studies have confirmed that corals also belong to heterotrophic organisms. Heterotrophic feeding is essential for overcoming nutrient deficiency. The preliminary results of this study indicate that Goniopora columna have high levels of proteases, and artificial feeds containing high protein can be used for feeding during aquaculture, which can increase the growth rate. In conclusion, we have initially explored that Goniopora columna will have better growth by feeding artificial PUFA rich in animal protein. In addition, the best feeding time is 6:00-12:00 in the morning, when there is better digestion and absorption. It is hoped that this research will be helpful to the development of coral aquaculture in the future.

Abstract: Nutritional requirements are critical in the process of coral aquaculture. In addition to energy from symbiotic algae, corals obtain sufficient nutrition through heterotrophic feeding. Microalgae and yeast are commonly used as nutritional supplements for many aquaculture organisms. In addition, if artificial feed can match or improve upon the nutritional supplementation provided by microalgae and yeast in the case of G. columna, then feeding this coral would be markedly easier. Hence, this article preliminarily discusses feeds suitable for G. columna. In this study, artificial PUFA rich in animal protein (R), Sacharomyces cerevisiae, Isochrysis galbana tml, and Nannochloropsis oculate were fed to G. columna at quantities of $5 \%$ and $10 \%$ of body weight. Growth, survival, body composition, and digestive enzymes were assessed. Regarding body composition, the coral's protein content is higher than that of carbohydrate or fat; thus, evaluating the heterotrophic nutrition of $G$. columna by using protein absorption is appropriate. The protease content is also high in digestive enzymes. Protein content, protease activity, and specific growth rate were significantly higher in the $\mathrm{R}$ group than in other groups. The number of polyps in the groups fed $\mathrm{R}$ at $5 \%$ and $10 \%$ of body weight increased by $40.00 \pm 2.43$ and $47.33 \pm 0.89$ number, respectively, significantly greater increases than those achieved in the other groups $(p<0.05)$. Changes in body composition and digestive enzymes over a 24 -h period were compared to determine the optimal feeding time. Protein content and protease activity increased markedly between 6:00 and 12:00. The experimental results suggest that $\mathrm{R}$ can improve the activity of G. columna digestive enzymes and their protein and lipid content in body tissue, shorten the cultivation time, and enhance the profitability of coral aquaculture.

Keywords: feeding; growth; digestive enzymes; Goniopora columna; scleractinian coral

\section{Introduction}

Coral reefs are considered the tropical rainforests of the sea because of their rich species diversity [1,2]. However, coral reefs are deteriorating at an alarming rate due to 
climate change, environmental pollution, and destructive fishing practices. Coral bleaching, which can lead to species extinction, is increasingly occurring. Coral husbandry can simultaneously address environmental conservation needs and the industrial demand for corals. According to the Convention on International Trade in Endangered Species of Wild Fauna and Flora (CITES), the total trade volume of Goniopora sp. from 2010 to 2020 accounted for $18 \%$ of the trade volume of all corals, amounting to US \$7.2 million (CITES, 2021). Although the species has noteworthy ornamental value, research has indicated that the mortality of Goniopora sp. in aquariums is as high as 95\% [3]. Aquaculture of coral offers an alternative to wild harvesting for the ornamental trade and shows considerable promise for restoring reefs and preserving biodiversity [4]. Goniopora columna is a scleractinian coral native to the western Pacific Ocean and the eastern and western Indian Ocean [2]. This reef-associated species, commonly known as a flowerpot coral, is primarily found in intertidal coral reefs and often forms large groups in muddy waters. Its corallites are $>5 \mathrm{~mm}$ in diameter, and its polyps are large, fleshy, and long. Tubular creatures with conical projections in the center of their tentacles, they live in seas rich with nutrients and can supplement heterotrophic nutrition with polyp hunting. G. columna are considered a heterotrophic coral. The autotrophic and heterotrophic nutrition of corals and the relative importance of these sources in their energy balance have long been recognized as key biological and ecological concerns. G. columna has both ecological and ornamental roles. Therefore, their reefs must be efficiently restored and protected; this can be achieved by determining the optimal culture conditions for G. columna. In addition to light and water flow, the organic matter or feed in the environment plays a crucial role in coral aquaculture [5].

Corals are heterotrophic organisms; heterotrophic feeding is essential for them if they are to avoid nutrient deficiency. Corals exhibit several modes of feeding and acquire energy from multiple sources [6]. In addition to obtaining nutrients from symbiotic algae, corals can feed on marine plankton, which provide essential amino acids and other nutrients not obtainable from symbiotic algae [6-9]. Numerous studies have reported that many species of corals are also active heterotrophs, ingesting bacteria, particulate organic matter, and even dissolved nutrients from water and mesozooplankton. Heterotrophy accounts for up to $66 \%$ of the fixed carbon incorporated into the skeleton of a coral and meets $15-35 \%$ of the daily metabolic requirements, contributing to the metabolic activity associated with zooxanthellae [10-20] Regarding the feeding habits of the coral Montastraea cavernosa, the larvae of copepods, amphipods, nemerteans, turbellarians, polychaetes, nematodes, appendicularians, salps, decapods, and cirripedes have been discovered in the coral body and planktonic algae [21] Studies have suggested that corals are polytrophic in nature [22].

To date, only a few studies have explored the nutrition and digestion of corals as well as whether feeding is required to induce a growth rate conducive to large-scale artificial cultivation. In coral aquaculture, asexual fragmentation is often used for propagation. The partitioned coral colony tends to be small, and the nutrients provided by coral symbiotic algae may be insufficient. Therefore, hunting heterotrophic nutrients to promote growth and accelerate tissue repair is necessary. The growth and survival of artificially cultured corals are affected by the quality of available nutrient sources [23]. Heterotrophic feeding enhances the growth, calcification rate, and photosynthesis rate of coral and even affects the symbiotic zooxanthellae [6,24-29]. Obtaining plankton from the ocean to feed coral in an aquarium is unsustainable and economically inefficient. A common initial diet in aquaculture comprises microalgae and yeast. Microalgae contain oil and unsaturated fatty acids, which can improve the nutrition, growth, and survival rate of fish fry. Yeast can provide nutritional supplement to promote the growth of some marine life and has also been proven to strengthen nonspecific immune responses [30,31]. Until now, no studies have evaluated the effects of microalgae, yeast, and artificial coral feed on G. columna nutrition. This study involved experiments to determine such effects of microalgae, yeast commonly used in aquaculture, and artificial coral feed. By analyzing the resultant body composition, changes in digestive enzymes, and growth of G. columna, we evaluated the 
suitability of these feeds and the optimal feeding time to indicate how the growth rate of $G$. columna during cultivation can be improved.

\section{Materials and Methods}

\subsection{Biological Materials}

G. columna (total of 100 colonies) was obtained from Coral King Coral Farm (Kaohsiung, Taiwan), a CITES-legal coral farm (no. FTS507W0153796), and were cultured in an aquarium tank $(60 \times 35 \times 30 \mathrm{~cm})$ by using a recirculating filtered seawater system. An HME Block 2 Series frame with purple light-emitting diode lights ( $400-430 \mathrm{~nm}$; photosynthetically active radiation [PAR] $71.03 \pm 0.21 \mu \mathrm{mol} \mathrm{m}^{-2} \mathrm{~s}^{-1}$ ) was set $30 \mathrm{~cm}$ above the glass aquarium's water surface. The PAR was detected using an Apogee Instruments MQ-510 underwater quantum meter (USA). The water quality was monitored daily during the experiment and maintained at a safe level. When corals were moved to a tank, they immediately produced abundant mucus to protect themselves from bacterial infection; therefore, pump-generated water flow was used to remove mucus from the corals' surface and prevent hypoxia, which would affect the corals' physiological metabolism, and tissue necrosis caused by the slimy covering [9]. Therefore, a water pump should be installed in aquariums to remove the mucus on the surface of corals by using water flow. After the corals had adapted to their environment, they were artificially propagated through fragmentation. In this study, after 2 months of acclimation and self-repair, healthy corals were segmented into groups, with each colony containing five polyps; then, they were fixed onto porous foundation stones by using coral glue. After approximately $72 \mathrm{~h}$ of tissue repair, the polyps were fully extended (to assess the tissue repair) and the experiment was started. All experiments were performed triplicate, and thus each group involved a total of 30 colonies.

\subsection{Experiment One: Feed Composition and Feeding}

\subsubsection{Feed Source}

The $\mathrm{R}$ diet contained a mixture of intact and hydrolyzed marine and terrestrial ingredients (commercial-in-confidence formulation, details not provided). The S, I, and N feeds were employed as plant feeds in this study. Microalgae in stock cultures were grown in a $2000 \mathrm{~mL}$ glass conical flask containing liquid Walne medium. High-temperature, high-pressure sterilization was applied $\left(121^{\circ} \mathrm{C}\right.$ for $\left.30 \mathrm{~min}\right)$. The culture was then cooled to $26^{\circ} \mathrm{C}$, and a fluorescence lamp with 12L/12D-h light-dark photoperiod was used for irradiation. Subcultures were then formed by transferring $400 \mathrm{~mL}$ of solution with viable microalgae cells to new medium every 1-2 months. The nutritional composition of all feeds is shown in Table 1.

Table 1. Nutrient composition of the various feeds.

\begin{tabular}{|c|c|c|c|c|}
\hline Nutritional Indicators & $\mathbf{R}$ & $S$ & I & $\mathbf{N}$ \\
\hline Protein & $76.67^{a}$ & $37.00^{d}$ & $66.00^{b}$ & $49.00^{c}$ \\
\hline$(\mu \mathrm{g})$ & -1.56 & -1.33 & -1.33 & -0.67 \\
\hline Lipid & $6.00^{c}$ & $5.00^{\mathrm{c}}$ & $32.00^{\mathrm{a}}$ & $20.33^{b}$ \\
\hline$(\mu \mathrm{g})$ & -0.67 & -1.33 & -2 & -1.56 \\
\hline Glucose & $22.00^{b}$ & $29.00^{\mathrm{a}}$ & $0.63^{c}$ & $0.67^{c}$ \\
\hline$(\mu \mathrm{g})$ & -0.67 & -0.67 & -0.16 & -0.11 \\
\hline
\end{tabular}

R: artificial PUFA rich in animal protein; S: Saccharomyces cerevisiae; I: Isochrysis galbana tml; N: Nannochloropsis oculata. Different letters indicate significant differences among groups $(p<0.05)$. Values are expressed as means $\pm \operatorname{SDs}(n=3)$.

\subsubsection{Coral Feeding}

In the coral feeding assessment, microscopic examination of the corals $1 \mathrm{~h}$ after feeding revealed the presence of microalgae and yeast in the corals' body cavities, but the $\mathrm{R}$ formulation could not be observed under a microscope because this commercial feed was a liquid. This study evaluated the coral feed's effects on nutrient uptake with reference 
to changes in the protein content of Psetta maxima L. levels by feeding plant proteins in accordance with the experimental method of [32]. The feeding density of microalgae and yeast was $5-6 \times 10^{5}$ cells $/ \mathrm{mL}$. When the density was too high, sterilized seawater was used for dilution. Microalgae, yeast, and $\mathrm{R}$ are all liquid, so $10 \%(w / v)$ of coral tissue and skeletal dry weight are used for feeding. Therefore, the protein, lipid, and carbohydrate content of the experimental corals (in their body composition) were compared with those of the unfed control group to determine whether food had been ingested. Protein, lipid, and glucose analysis was performed $1 \mathrm{~h}$ after feeding.

\subsubsection{Analysis of Coral Body Composition and Feed}

In this study, in addition to analyzing the body composition analysis of the corals, feed analysis was conducted for data comparison. Each group of feeds was centrifuged to obtain $1 \mathrm{mg}$ as a sample for analysis. G. columna were sonicated and protein concentrations were measured using a Bradford protein assay kit (Ameresco, Solon, OH, USA) with bovine serum albumin as a protein standard. Lipids content analysis was performed using the soxhlet extractor methods [33]. The total lipid weight was determined $( \pm 0.0001 \mathrm{~g})$, and the derived weight values were converted into micrograms $\left(1 \mathrm{~g}=1 \times 10^{6} \mu \mathrm{g}\right)$. Glucose detection is based on the Enzymatic, Colorimetric method (GOD/PAP) with glucose oxidase, and 4-aminoantipyrine [34,35].

\subsection{Experiment Two: Effects of Different Diets on Body Composition, Digestion Enzyme, Growth and Survival of Coral}

\subsubsection{Experimental Conditions}

In this study, artificial polyunsaturated fatty acid (PUFA) rich in animal protein (R; i.e., a formulated diet combining animal protein and sodium alginate with probiotics), Saccharomyces cerevisiae (S), Isochrysis galbana tml (I), and Nannochloropsis oculata (N) were used as the feeds for the experimental groups; an unfed control group (C) was also included in the study. The feeding density of microalgae and yeast was $5-6 \times 10^{5}$ cells $/ \mathrm{mL}$, and the feeding amount was either $5 \%$ (denoted 5$)$ or $10 \%(10)$ of the coral's body weight $(w / v)$, such that the experimental groups are represented as $R(5), S(5), I(5), N(5), R(10), S(10)$, $\mathrm{I}(10)$, and $\mathrm{N}(10)$ and the control group as C, each with three respective replicates. The diet formula was improved after reference to the work of [36-38]. We have studied this feed and hope to successfully conduct large-scale G. columna culture. Each treatment group had triplicate (with 10 colonies each) and a total of 30 colonies. The water quality conditions were summarized in Table 2. The experiment lasted for eight weeks. After the experiment, the initial and final weights were measured to calculate the specific growth rate (SGR), body composition, digestion enzyme, zooxanthellae, and chlorophylla.

Table 2. Water quality conditions.

\begin{tabular}{|c|c|c|c|c|c|c|c|c|c|}
\hline \multicolumn{6}{|c|}{$5 \%$} & \multicolumn{4}{|c|}{$10 \%$} \\
\hline $\begin{array}{l}\text { Water Quality } \\
\text { Conditions }\end{array}$ & $\mathrm{C}$ & $\mathbf{R}$ & S & $\mathbf{I}$ & $\mathbf{N}$ & $\mathbf{R}$ & S & $\mathbf{I}$ & $\mathbf{N}$ \\
\hline Temperature $\left({ }^{\circ} \mathrm{C}\right)$ & $26.03(0.24)$ & $26.19(0.14)$ & $26.20(0.21)$ & $26.32(0.19)$ & $26.31(0.15)$ & $26.21(0.21)$ & $26.03(0.24)$ & $26.47(0.52)$ & $26.93(0.33)$ \\
\hline Salinity (PSU) & $35.04(0.22)$ & $35.21(0.39)$ & $35.12(0.17)$ & $35.21(0.12)$ & $34.22(0.82)$ & $35.21(0.19)$ & $35.12(0.11)$ & $34.20(0.21)$ & $35.04(0.19)$ \\
\hline pHAmmonia nitrogen & $8.01(0.31)$ & $8.03(0.21)$ & $8.12(0.42)$ & $8.05(0.13)$ & $8.21(0.42)$ & $8.21(0.93)$ & $8.04(0.21)$ & $8.21(0.48)$ & $8.21(0.24)$ \\
\hline$(\mathrm{mg} / \mathrm{L})$ & $0.04(0.01)$ & $0.04(0.02)$ & $0.04(0.03)$ & $0.05(0.02)$ & $0.04(0.03)$ & $0.04(0.02)$ & $0.04(0.04)$ & $0.03(0.01)$ & $0.03(0.01)$ \\
\hline Nitrous acid (mg/L) & $0.02(0.01)$ & $0.02(0.01)$ & $0.02(0.01)$ & $0.01(0.01)$ & $0.02(0.01)$ & $0.02(0.01)$ & $0.02(0.01)$ & $0.02(0.01)$ & $0.02(0.01)$ \\
\hline Nitric acid (PPM) & $0.20(0.03)$ & $0.18(0.04)$ & $0.30(0.02)$ & $0.13(0.02)$ & $0.05(0.02)$ & $0.25(0.08)$ & $0.20(0.02)$ & $0.19(0.04)$ & $0.20(0.03)$ \\
\hline Calcium (PPM) & $409(42.32)$ & 415 (33.92) & $410(13.03)$ & $418(20.03)$ & $424(32.01)$ & $412(34.21)$ & 427 (12.15) & $413(30.21)$ & $410(30.22)$ \\
\hline Magnesium (PPM) & $1385(69.12)$ & $1350(63.29)$ & 1349 (31.03) & $1320(22.43)$ & $1381(53.22)$ & $1351(21.04)$ & $1328(31.26)$ & $1365(23.41)$ & $1350(30.34)$ \\
\hline Phosphate (PPM) & $0.02(0.01)$ & $0.02(0.01)$ & $0.02(0.01)$ & $0.02(0.01)$ & $0.02(0.01)$ & $0.02(0.01)$ & $0.02(0.01)$ & $0.02(0.01)$ & $0.02(0.01)$ \\
\hline
\end{tabular}

Values are expressed as mean \pm standard deviation (SD; $n=56$ days); C: no feeding; R: artificial polyunsaturated fatty acid (PUFA) rich in animal protein; S: Saccharomyces cerevisiae; I: Isochrysis galbana tml; N: Nannochloropsis oculate. 


\subsubsection{Coral Feeding}

After shaking the microalgae and yeast evenly, $20 \mu \mathrm{L}$ was absorbed by a micropipette (adjustable air-displacement pipette M25) and then used to calculate the number of microalgae and yeast cells with a hemocytometer [26]. The cultured microalgae and yeast were first counted by hemocytometer, and then diluted with sterilized seawater to the desired feeding density. The feeding density of microalgae and yeast was $5-6 \times 10^{5}$ cells $/ \mathrm{mL}$. Microalgae, yeast, and R were liquid and fed $5 \%$ and $10 \%(w / v)$ of coral tissue and skeletal dry weight per day. Feeding occurred daily at 8:00, except in the case of the unfed control group.

\subsubsection{Determination of Coral Growth and Polyp Count}

Coral growth was determined on the basis of total weight and polyp count as described by [39,40]. We followed Hii et al. [6] by sampling and analyzing the different feed groups $1 \mathrm{~h}$ after feeding. We measured the tissue and skeletal dry weight. Algae were brushed and the coral surfaces were dusted off and then placed on a plastic petri dish. Subsequently, a coral's weight was measured using an electronic balance. G. columna has a large polyp that can be observed directly with the naked eye. Calculations were made once a week, and photographs to record the number of new polyps were taken using a Canon EOS 750D camera. The SGR of the coral was measured using the following formula:

$$
\operatorname{SGR}\left(\% \text { day }-{ }^{1}\right)=\left(\frac{\operatorname{In}(w f)-\operatorname{In}(w i)}{\Delta \mathrm{t}}\right) \times 100
$$

where $w i$ is the initial weight of the coral $(\mathrm{g})$, wf is the final weight of the coral $(\mathrm{g})$ and $\Delta \mathrm{t}$ is the number of experimental days.

The tissue and skeletal dry weight and number of polyps were measured every 7 days. SGRs as mean values with standard deviations (SDs) were calculated after the experiment. After the experiment, to calculate the survival of the corals, the disappearance of polyps was considered to indicate their death. The survival rates, expressed as means (\%) with SDs, were calculated using the following formula:

$$
\text { survival rate }(\%)=\frac{(\text { number of final living specimens })}{(\text { number of initial specimens })} \times 100
$$

\subsubsection{Analysis of Zooxanthellae Density and Chlorophyll a}

After the eight-week experiment, coral tissues were homogenized and zooxanthellae density was calculated according to Titlyanov et al. [26] method. Chlorophyll a concentration was determined by Hitachi U-2000 spectrophotometer at $630 \mathrm{~nm}$ and $664 \mathrm{~nm}$ in reference to Levy et al. [41] and Titlyanov et al. [26] method. Calculated using an equation developed by Jeffrey \& Humphrey [42], the value represents how many micrograms of chlorophyll a there are per gram of coral tissue.

\subsubsection{Analysis of Coral Body Composition and Digestive Enzymes}

For coral body composition test, please refer to materials and methods 2.2.3. Enzyme extraction was performed using the method of Sun et al. [43]. Protease and lipase extractions were performed using $10 \mathrm{mM}$ sodium citrate buffer ( $\mathrm{pH}$ 7.0) in a cold environment. Each coral was first rinsed in buffer solution and then added to 10 times the volume of buffer solution, placed on ice for grinding, and subsequently centrifuged $(10,000 \times g)$ at $4{ }^{\circ} \mathrm{C}$ for $10 \mathrm{~min}$. Thereafter, the supernatant was collected and stored at $-20^{\circ} \mathrm{C}$. Protease content was analyzed using the method of Sun et al. [43], which involved adding $1 \mathrm{~mL}$ of casein to $0.5 \mathrm{~mL}$ of enzyme extract, incubating the mixture for $15 \mathrm{~min}$, and then adding $1.5 \mathrm{~mL}$ of $10 \%$ trichloroacetic acid. After centrifuging $(6000 \times \mathrm{g})$ at $4{ }^{\circ} \mathrm{C}$ for $10 \mathrm{~min}$, the supernatant was collected and $5 \mathrm{~mL}$ of $0.55 \mathrm{M} \mathrm{Na}_{2} \mathrm{CO}_{3}$ and $1 \mathrm{~mL}$ of Folin phenol-staining reagent were added. The absorbance value at $680 \mathrm{~nm}$ was observed. Lipase content was analyzed using the method of Borlongan [44]. To $1.5 \mathrm{~mL}$ of olive oil, $1.5 \mathrm{~mL}$ of Tris- $\mathrm{HCl}$ 
(0.1 $\mathrm{M}$ buffer, $\mathrm{pH} 8.0$ ) and $1 \mathrm{~mL}$ of enzyme extract were added, and the solution was then shaken at $37{ }^{\circ} \mathrm{C}$ for $6 \mathrm{~h}$. Thereafter, 95\% alcohol was added to terminate the reaction, and thymolphthalein containing $0.9 \%$ alcohol was used as the indicator. The mixture was then titrated with $0.01 \mathrm{~N} \mathrm{NaOH}$ until the solution turned brown. Amylase content was analyzed using the method of Bernfeld [45]. To $0.05 \mathrm{M}$ phosphate buffer solution ( $\mathrm{pH} 7.0$ ), $1 \mathrm{~mL}$ of $2 \%(w / v)$ starch solution was added, and the mixture was maintained at $25{ }^{\circ} \mathrm{C}$ for $5 \mathrm{~min}$. Then, the enzyme extraction was added and the mixture was left to react at 20-60 ${ }^{\circ} \mathrm{C}$. Subsequently, $2 \mathrm{~mL}$ of dinitrosalicylic acid reagent was added before the reaction was stopped in a boiling water bath for $5 \mathrm{~min}$ and the mixture then cooled. The absorbance at $520 \mathrm{~nm}$ was measured, as per the maltose standard. Amylase activity was determined as maltose content per milligram of protein per minute. At the end of the experiment, means and SDs were calculated.

\subsection{Experiment Three: Diurnal Change Analysis of Coral Body Composition and Digestive Enzymes}

G. columna were fed in an aquarium $(60 \times 35 \times 30 \mathrm{~cm})$ containing a recirculating filtered seawater system. The photoperiod was set as $6 / 18$-h light-dark. In this experiment, $\mathrm{R}$ was used for feeding, feeding at the same time at the beginning of the experiment, feeding $10 \%(w / v)$ of the tissue and skeletal dry weight of coral. Samples were obtained every $6 \mathrm{~h}$, at 6:00,12:00, 18:00, and 24:00. The corals' body composition and digestive enzymes were analyzed after sampling ( $n=30$ colonies). The purpose of this study was to determine at which time of day corals should be fed to maximize digestion and absorption.

\subsection{Statistical Analysis}

Data were obtained from three independent experiments, and the final results are presented as means \pm SDs. One-way analysis of variance and Duncan's multiple range test were used to determine the statistical significance of G. columna nutrient composition, growth, survival, digestive enzyme activity, and body composition. A $p$ value $<0.05$ was considered significant. All statistical analyses were performed using IBM SPSS version 20. These analyses were used evaluate the feeding efficiency and feed time of corals on different foods.

\section{Results}

\subsection{Experiment One: Feed Composition and Ingestion Effects of Feed on Nutrient Intake}

Protein, lipid, and glucose analyses were performed $1 \mathrm{~h}$ after feeding (Table 3 ) and used to evaluate the changes in body composition of the corals after ingestion of feed compared with the unfed control group. After the G. columna were fed R, S, I, and N for $1 \mathrm{~h}$, various changes in their composition were immediately observed; their protein content was $430.45 \pm 12.30,322.05 \pm 11.22,332.35 \pm 13.12$, and $325.43 \pm 13.20 \mu \mathrm{g} / \mathrm{mg}$, respectively. The R-fed groups contained significantly more protein $(p<0.05)$ than the other groups. The lipid content was higher in the I and N groups, but the differences compared with the other groups were significant. The $S$ groups contained more glucose.

The $\mathrm{R}$ feed contained the most protein $(76.67 \pm 1.56 \mu \mathrm{g} / \mathrm{mg})$, the $\mathrm{I}$ and $\mathrm{N}$ feeds contained the most lipids (32.00 \pm 2.00 and $20.33 \pm 1.56 \mu \mathrm{g} / \mathrm{mg}$, respectively), and the $S$ feed was the highest in glucose $(29.00 \pm 0.67 \mu \mathrm{g} / \mathrm{mg})$ (Table 1). Therefore, the results indicated that G. columna could increase some bodily nutrients through the intake of different feeds.

3.2. Experiment Two: Effects of Different Diets on Body Composition, Digestion Enzyme, Growth and Survival of Coral

\subsubsection{Effects of Feed on Growth and Survival of G. Columna}

After 8 weeks of cultivation, the polyp numbers, tissue and skeletal dry weight measurements, and the SGRs of the corals were used to evaluate the growth of G. columna. 
As shown in Table 4, the numbers of polyps in the $\mathrm{R}(5)$ and $\mathrm{R}(10)$ groups were $40.00 \pm 2.43$ number and $47.33 \pm 0.89$ number, respectively, significantly higher than those in other groups fed $5 \%$ or $10 \%$ of their body weight $(p<0.05)$. The $S(5)$ and $N(5,10)$ groups had the fewest polyps, with only 32 remaining after 8 weeks of culture. The R groups significantly outgrew all the other groups $(p<0.05)$. The $G$. columna exhibited stunted growth when fed the $S, I$, and $\mathrm{N}$ feeds. The changes in coral tissue and skeleton dry weights indicated that the $\mathrm{R}(10)$ group demonstrated the greatest tissue and skeletal dry weight gain (12.93 $\pm 0.4 \mathrm{mg}$; Figure 1). Figure 2 illustrates the SGR of the G. columna specimens. The SGRs of the R(5) and $\mathrm{R}(10)$ groups were 1.3 times those of the S, I, and $\mathrm{N}$ groups (for both $5 \%$ and $10 \%$ of body weight feeding). These results reveal that the selection of feed is crucial to G. columna growth. The $\mathrm{R}$ feed enhanced the growth of $\mathrm{G}$. columna. In each group, the survival rate was $100 \%$; no deaths were recorded. Thus, feeding with the $\mathrm{R}$ formulation effectively promotes G. columna growth.

Table 3. Body composition of corals $1 \mathrm{~h}$ after being fed different aquaculture feeds.

\begin{tabular}{|c|c|c|c|c|c|}
\hline \multirow{2}{*}{$\begin{array}{l}\text { Nutritional } \\
\text { Indicators }\end{array}$} & \multicolumn{5}{|c|}{ Feeding } \\
\hline & $\mathrm{C}$ & $\mathbf{R}$ & $S$ & I & $\mathbf{N}$ \\
\hline \multirow{2}{*}{ Protein $(\mu \mathrm{g} / \mathrm{mg})$} & $321.52^{b}$ & $430.45^{\mathrm{a}}$ & $322.05^{b}$ & $332.35^{\mathrm{b}}$ & $325.43^{b}$ \\
\hline & -11.51 & -12.3 & -11.22 & -13.12 & -13.2 \\
\hline \multirow{2}{*}{ Lipid ( $\mu \mathrm{g} / \mathrm{mg})$} & $1.10^{\mathrm{b}}$ & $1.20^{b}$ & $1.40^{\mathrm{b}}$ & $3.11^{\mathrm{a}}$ & $2.85^{\mathrm{a}}$ \\
\hline & -0.15 & -0.11 & -0.12 & -0.21 & 0.14 \\
\hline \multirow{2}{*}{ Glucose $(\mu \mathrm{g} / \mathrm{mg})$} & $1.11^{\mathrm{c}}$ & $3.93^{b}$ & $4.82^{\mathrm{a}}$ & $1.15^{\mathrm{c}}$ & $1.14^{\mathrm{c}}$ \\
\hline & -0.06 & -0.31 & -0.06 & -0.12 & -0.09 \\
\hline
\end{tabular}

C: no feeding; R: artificial polyunsaturated fatty acid (PUFA) rich in animal protein; S: Saccharomyces cerevisiae; I: Isochrysis galbana tml; N: Nannochloropsis oculata. Different letters indicate significant differences among groups $(p<0.05)$. Values are expressed as means \pm SDs $(n=30$ colonies $)$.

Table 4. Polyp number, zooxanthellae density, and chlorophyll a concentration of G. columna after 8 weeks of daily feeding.

\begin{tabular}{|c|c|c|c|c|c|c|}
\hline Treatments & Feed & $\begin{array}{l}\text { Zooxanthellae } \\
\left(\text { Cells } \times 10^{7} \mathrm{~m}^{2}\right)\end{array}$ & $\begin{array}{c}\text { Chlorophyll a } \\
\left(\mu \mathrm{g} / \mathrm{cm}^{2}\right)\end{array}$ & $\begin{array}{c}\text { Initial Polyps } \\
\text { (Number } \pm 95 \%)\end{array}$ & $\begin{array}{c}\text { End Polyp } \\
\text { (Number } \pm 95 \%)\end{array}$ & $\begin{array}{c}\text { Net Increase } \\
\text { (Number } \pm 95 \%)\end{array}$ \\
\hline \multirow{5}{*}{$5 \%$} & $\mathrm{C}$ & $3.71(0.17)$ & $53.22(1.04)$ & $5.00(0.00)$ & $33.00(1.37)$ & $28.00(1.37)$ \\
\hline & $\mathrm{R}$ & $4.05(0.71)$ & $54.29(1.23)$ & $5.00(0.00)$ & $40.00(2.34)$ & $35.00(2.34)$ \\
\hline & $S$ & $3.79(1.43)$ & $53.73(1.17)$ & $5.00(0.00)$ & $32.67(2.22)$ & $27.67(2.22)$ \\
\hline & $\mathrm{I}$ & $3.98(0.94)$ & $53.98(1.39)$ & $5.00(0.00)$ & $34.00(0.67)$ & $29.00(0.67)$ \\
\hline & $\mathrm{N}$ & $4.12(1.02)$ & $54.05(0.28)$ & $5.00(0.00)$ & $32.33(1.56)$ & $27.33(1.56)$ \\
\hline \multirow{4}{*}{$10 \%$} & $\mathrm{R}$ & $3.93(1.76)$ & $54.02(1.32)$ & $5.00(0.00)$ & $47.33(0.89)$ & $42.33(0.89)$ \\
\hline & $S$ & $4.21(1.53)$ & $53.69(1.75)$ & $5.00(0.00)$ & $35.35 .00(2.00)$ & $30.00(2.00)$ \\
\hline & $\mathrm{I}$ & $4.27(0.92)$ & $54.38(1.43)$ & $5.00(0.00)$ & $36.00(0.67)$ & $31.00(0.67)$ \\
\hline & $\mathrm{N}$ & $4.36(1.47)$ & $54.64(0.00)$ & $5.00(0.00)$ & 32.67 (1.78) & $27.67(1.78)$ \\
\hline
\end{tabular}

C: no feeding; R: artificial polyunsaturated fatty acid (PUFA) rich in animal protein; S: Saccharomyces cerevisiae; I: Isochrysis galbana tml; N: Nannochloropsis oculate. Values are expressed as means \pm SDs ( $n=30$ colonies).

\subsubsection{Influence of Different Feeds on Body Composition}

To determine whether a selected feed affected the body composition of G. columna, the various feeds $(R, S, I$, and $N)$ were given to the corals at quantities of either $5 \%$ or $10 \%$ of their body weight per day. After 8 weeks of cultivation, the body composition of the G. columna specimens was measured. Table 5 indicates that the protein content of the corals sustained with $\mathrm{R}$ feed was $474.01 \pm 23.00$ and $486.78 \pm 36.41 \mu \mathrm{g} / \mathrm{mg}$ for those fed $5 \%$ and $10 \%$ of their body weight, respectively; this content was significantly higher than that of the other groups $(p<0.05)$. The lipid content of the $R(5)$ and $R(10)$ groups was $2.85 \pm 0.13$ and $3.02 \pm 0.29 \mu \mathrm{g} / \mathrm{mg}$, respectively, significantly higher than the values in the other groups $(p<0.05)$. There was no significant difference in glucose content among all treatments. According to body composition analysis, the protein content of G. columna is 166 and 370 times higher than that of lipid and glucose. Feeding high protein content of 
R helps G. columna to growth. According to the preliminary results, G. columna exhibits notable potential to absorb protein nutrients, which could boost their growth.

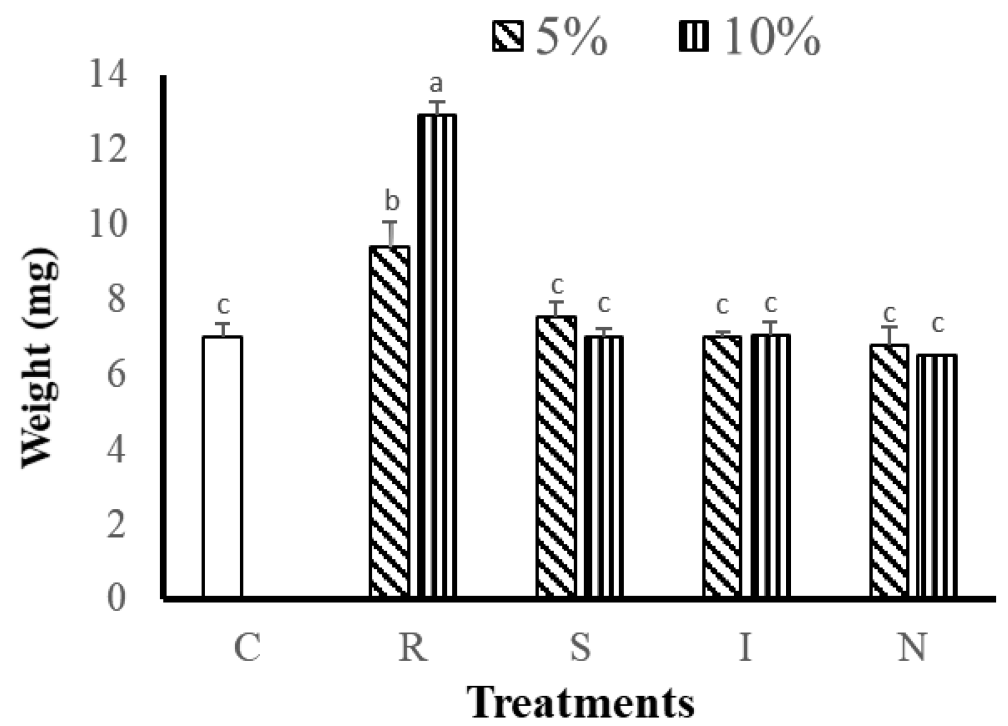

Figure 1. Tissue and skeletal dry weight of G. columna after 8 weeks of daily feeding with various aquaculture feeds. C: no feeding; R: artificial polyunsaturated fatty acid (PUFA) rich in animal protein; S: Saccharomyces cerevisiae; I: Isochrysis galbana tml; N: Nannochloropsis oculata. Different letters indicate significant differences among groups $(p<0.05)$. Values are expressed as means \pm SDs ( $n=30$ colonies).

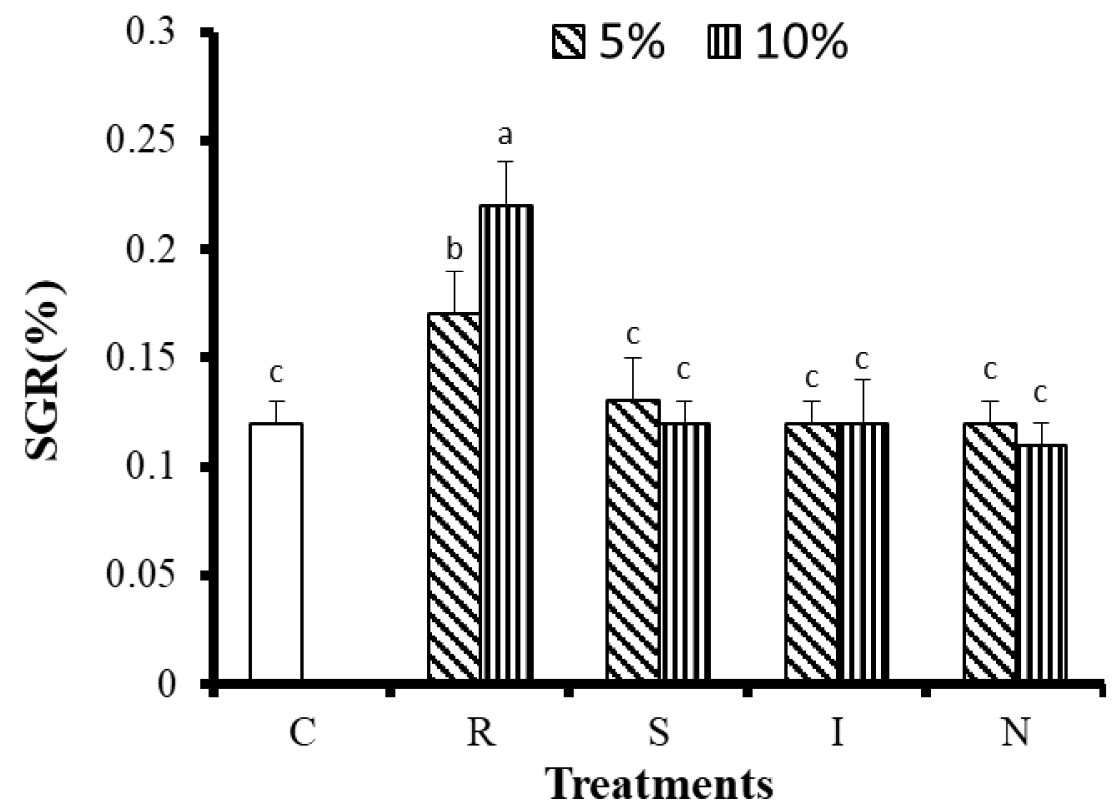

Figure 2. Growth of G. columna after 8 weeks of daily feeding. C: no feeding; R: artificial polyunsaturated fatty acid (PUFA) rich in animal protein; S: Saccharomyces cerevisiae; I: Isochrysis galbana tml; $\mathrm{N}$ : Nannochloropsis oculata. Different letters indicate significant differences among groups $(p<0.05)$. Values are expressed as means \pm SDs ( $n=30$ colonies). 
Table 5. Body composition of G. columna after 8 weeks of feeding with different aquaculture feeds.

\begin{tabular}{|c|c|c|c|c|c|c|c|c|c|}
\hline \multirow{3}{*}{$\begin{array}{l}\text { Nutritional } \\
\text { Indicators }\end{array}$} & \multicolumn{9}{|c|}{ Treatments } \\
\hline & \multirow{2}{*}{ C } & \multicolumn{2}{|c|}{$\mathbf{R}$} & \multicolumn{2}{|c|}{ S } & \multicolumn{2}{|c|}{ I } & \multicolumn{2}{|c|}{$\mathbf{N}$} \\
\hline & & $5 \%(\mathrm{I})$ & $10 \%$ (II) & $5 \%(I)$ & $10 \%$ (II) & $5 \%(\mathrm{I})$ & $10 \%$ (II) & $5 \%(I)$ & $10 \%$ (II) \\
\hline $\begin{array}{l}\text { Protein } \\
(\mu \mathrm{g} / \mathrm{mg})\end{array}$ & $\begin{array}{c}374.73^{b} \\
(11.50)\end{array}$ & $\begin{array}{c}474.01^{\mathrm{a}} \\
(23.00)\end{array}$ & $\begin{array}{c}486.78^{a} \\
(36.41)\end{array}$ & $\begin{array}{c}327.72^{b} \\
(21.80)\end{array}$ & $\begin{array}{c}383.18^{b} \\
(12.60)\end{array}$ & $\begin{array}{c}386.87^{b} \\
(12.60)\end{array}$ & $\begin{array}{c}385.57^{b} \\
(19.80)\end{array}$ & $\begin{array}{c}339.23^{b} \\
(12.14)\end{array}$ & $\begin{array}{c}321.79^{b} \\
(8.85)\end{array}$ \\
\hline Lipid & $1.96^{b}$ & $2.85^{a}$ & $3.02^{a}$ & $1.65^{\mathrm{b}}$ & $1.72^{b}$ & $1.98^{b}$ & $2.13^{b}$ & $1.69^{b}$ & $1.64^{b}$ \\
\hline$(\mu \mathrm{g} / \mathrm{mg})$ & $(0.15)$ & $(0.13)$ & $(0.29)$ & $(0.15)$ & $(0.10)$ & $(0.12)$ & $(0.21)$ & $(0.42)$ & $(0.14)$ \\
\hline Glucose & 1.11 & 1.28 & 1.32 & 1.13 & 1.26 & 1.22 & 1.15 & 1.13 & 1.11 \\
\hline$(\mu \mathrm{g} / \mathrm{mg})$ & $(0.06)$ & $(0.20)$ & $(0.22)$ & $(0.07)$ & $(0.06)$ & $(0.09)$ & $(0.12)$ & $(0.07)$ & $(0.09)$ \\
\hline
\end{tabular}

C: no feeding; R: artificial PUFA rich in animal protein; S: Saccharomyces cerevisiae; I: Isochrysis galbana tml; N: Nannochloropsis oculata. Different letters indicate significant differences among groups $(p<0.05)$. Values are expressed as means \pm SDs $(n=30$ colonies).

\subsubsection{Influence of Different Feeds on Digestive Enzymes}

After the corals had been given different feeds (R, S, I, and N) for 8 weeks, their digestive enzyme activity was measured. As detailed in Table 6, the protease activity of the $R(5)$ and $R(10)$ groups was 1.57 and $1.67,1.78$ and $1.93,1.69$ and 1.71 , and 1.51 and 1.52 times higher than that of S, I, N, and unfed control (C) groups, respectively. Similarly, the lipase activity of the $\mathrm{R}(5)$ and $\mathrm{R}(10)$ groups was 1.21 and $1.27,1.29$ and $1.27,1.34$ and 1.36 , and 1.21 and 1.28 times higher than that of their counterpart $\mathrm{S}, \mathrm{I}, \mathrm{N}$, and $\mathrm{C}$ groups. No significant differences in amylase activity were discovered among any of the groups. These results indicate that $R$ feeding can enhance protease and lipase activities (but not amylase activity) in G. columna. Therefore, the intake of high-protein food is more conducive to nutrient absorption in G. columna.

Table 6. Activity of digestive enzymes in G. columna after 8 weeks of feeding with different aquaculture feeds.

\begin{tabular}{|c|c|c|c|c|c|c|c|c|c|}
\hline \multirow{3}{*}{ Test Items } & \multicolumn{9}{|c|}{ Treatments } \\
\hline & \multirow{2}{*}{$\mathrm{C}$} & \multicolumn{2}{|c|}{$\mathbf{R}$} & \multicolumn{2}{|c|}{$S$} & \multicolumn{2}{|c|}{ I } & \multicolumn{2}{|c|}{$\mathbf{N}$} \\
\hline & & $5 \%(\mathrm{I})$ & $10 \%$ (II) & $5 \%(\mathrm{I})$ & $10 \%$ (II) & $5 \%(I)$ & $10 \%$ (II) & $5 \%(I)$ & $10 \%$ (II) \\
\hline Protease & $214.37^{b}$ & $324.67^{a}$ & $325.70^{a}$ & $206.24^{b}$ & $196.66^{b}$ & $182.13^{b}$ & $168.68^{b}$ & $191.75^{b}$ & $190.17^{b}$ \\
\hline (U/mg protein) & $(11.22)$ & $(26.68)$ & $(34.88)$ & $(7.31)$ & (12.13) & $(42.85)$ & $(30.17)$ & $(35.94)$ & $(33.92)$ \\
\hline Lipase & 10.01 & 12.16 & 12.84 & 10.04 & 10.13 & 9.42 & 10.30 & 9.09 & 9.42 \\
\hline (U/mg protein) & $(0.80)$ & $(0.52)$ & $(0.43)$ & $(0.39)$ & $(0.37)$ & $(0.64)$ & $(0.42)$ & $(1.30)$ & $(0.64)$ \\
\hline Amylase & 1.47 & 1.45 & 1.61 & 1.38 & 1.17 & 1.27 & 1.26 & 1.18 & 1.26 \\
\hline (U/mg protein) & $(0.08)$ & $(0.15)$ & $(0.24)$ & $(0.43)$ & $(0.54)$ & $(0.08)$ & $(0.06)$ & $(0.52)$ & $(0.58)$ \\
\hline
\end{tabular}

C: no feeding; R: artificial PUFA rich in animal protein; S: Saccharomyces cerevisiae; I: Isochrysis galbana tml; N: Nannochloropsis oculata. Different letters indicate significant differences among groups $(p<0.05)$. Values are expressed as means \pm SDs $(n=30$ colonies $)$.

\subsubsection{Influence of Different Feeds on Zooxanthellae and Chlorophyll a}

By observing the changes of zooxanthellae and chlorophyll A, it can be judged that light energy or feed can provide nutrients to promote coral growth. As detailed in Table 4 , no significant differences in zooxanthellae density (approximately $4.0 \times 10^{7}$ cells m $\mathrm{m}^{-2}$ ) or chlorophyll a concentration (approximately $54 \mu \mathrm{g} \mathrm{cm}^{-2}$ ) were noted among the groups fed different substances. Therefore, the experimental results showed that there was no significant increase in the number of zooxanthellae, but feeding $\mathrm{R}$ could promote the growth of coral.

\subsection{Experiment Three: Coral Feeding Time Assessment}

The present study suggested that the artificial feed $\mathrm{R}$ enhances the growth, body composition, and digestive enzyme activity of G. columna. Changes in the body composition and digestive enzymes of G. columna were observed after feeding with R over a 24-h period. By measuring the changes in digestive enzymes and body composition, the feeding time most conducive to growth within coral aquaculture was evaluated. Figure 3 illustrates 
that the protein content of G. columna at 6:00, 12:00, 18:00, and 00:00 was 354.21 \pm 21.64 , $486.78 \pm 23.12,324.13 \pm 21.03$, and $321.49 \pm 19.46 \mu \mathrm{g} / \mathrm{mg}$, respectively. The protease activity at 12:00 was $1.37,1.50$, and 1.51 times higher than that at 6:00, 18:00, and 00:00, respectively. Lipid content was continually low $(2.49-3.02 \mu \mathrm{g} / \mathrm{mg})$. No significant differences in glucose content were observed among the four feeding times $(1.02-1.38 \mu \mathrm{g} / \mathrm{mg})$. As shown in Table 7, the protease activity at 6:00, 12:00, 18:00, and 00:00 was 153.25 \pm 20.32 , $385.67 \pm 16.48,285.15 \pm 17.12$, and $167.85 \pm 19.35 \mathrm{U} / \mathrm{mg}$ protein, respectively. The protease activity at $12: 00$ was $2.52,1.35$, and 2.30 times higher than that at 6:00, 18:00, and 00:00, respectively. No significant differences were observed in the lipase or amylase activity among different feeding times. An in vivo comparison of the protease activity with protein content suggested that the protein content was lower when the protease activity was lower. The protein content and protease activity were both at their highest at 12:00 and both decreased in the evening to their lowest values at 00:00. Therefore, the experimental results suggest that the digestion and absorption of G. columna exhibit hour-to-hour changes across the daily cycle. The most suitable feeding time for $G$. columna culture is between 6:00 and 12:00, during which the digestive enzyme activity gradually increases and the absorption of nutrients from the feed is optimal.

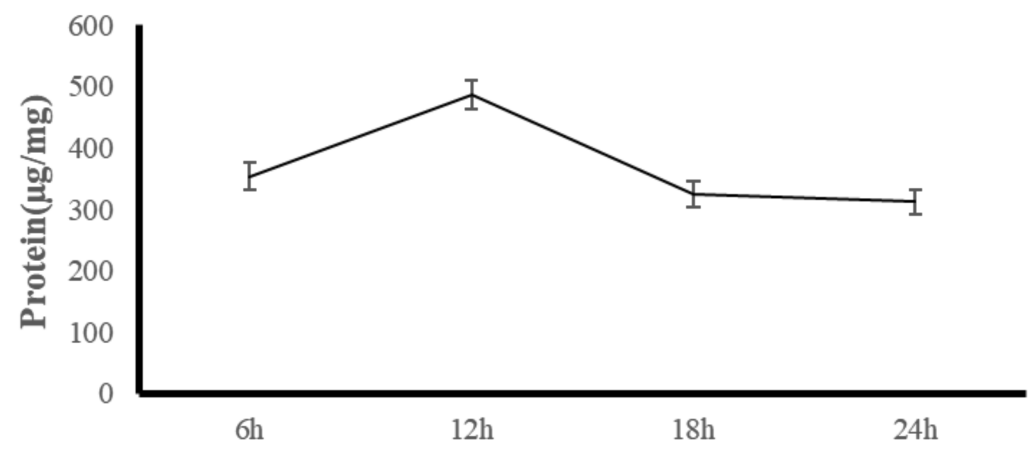

(A)

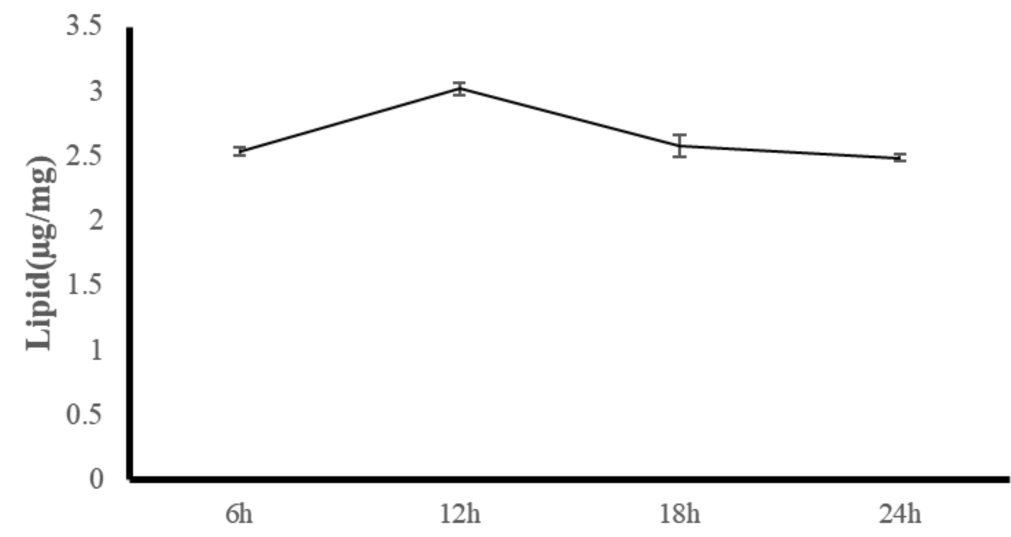

(B)

Figure 3. Cont. 


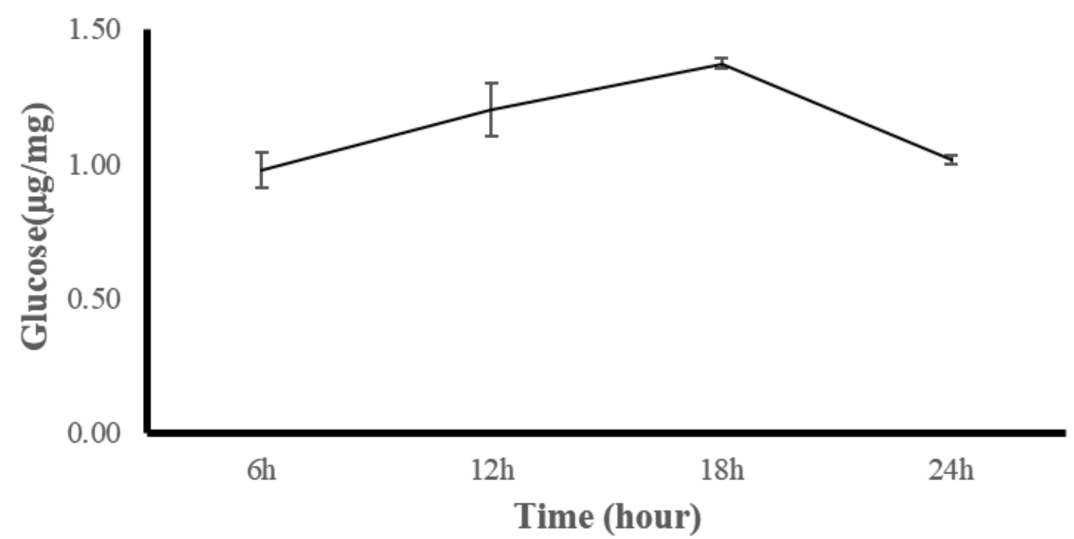

(C)

Figure 3. Changes in body composition of rich-animal-protein-fed (R-fed) G. columna over a 24-h period: (A) protein, (B) lipid, and (C) glucose content. Values are expressed as means \pm SDs $(n=30$ colonies $)$.

Table 7. Changes in digestive enzymes of R-fed G. columna over a 24-h period.

\begin{tabular}{ccccc}
\hline Test Items & $\mathbf{6}$ & $\mathbf{1 2}$ & $\mathbf{1}$ & $\mathbf{1 0}$ \\
\hline $\begin{array}{c}\text { Protease } \\
\mathrm{U} / \text { mg protein }\end{array}$ & $153.25(20.32)^{\mathrm{c}}$ & $385.67(16.48)^{\mathrm{a}}$ & $285.15(17.12)^{\mathrm{b}}$ & $167.85(19.35)^{\mathrm{c}}$ \\
\hline $\begin{array}{c}\text { Lipase } \\
\mathrm{U} / \text { mg protein }\end{array}$ & $4.01(0.08)^{\mathrm{c}}$ & $10.16(0.52)^{\mathrm{a}}$ & $9.06(0.42)^{\mathrm{b}}$ & $4.39(0.12)^{\mathrm{c}}$ \\
\hline $\begin{array}{c}\text { Amylase } \\
\mathrm{U} / \text { mg protein }\end{array}$ & $0.95(0.21)$ & $1.29(0.11)$ & $1.17(0.08)$ & $1.04(0.16)$ \\
\hline
\end{tabular}

Different letters indicate significant differences among groups $(p<0.05)$. Values are expressed as means \pm SDs $(n=30$ colonies $)$

\section{Discussion}

Among ornamental corals, G. columna is an industry favorite. The scarcity of data on the effects of various coral feeds and corals' nutritional requirements renders feeding within coral aquaculture difficult [6]. G. columna cultures can be influenced by environmental factors, and quantitative feeding can enhance the growth of polyps. Our results revealed that G. columna gained effective sustenance from the $\mathrm{R}$ formulation. The $\mathrm{R}(10)$ group exhibited an increase in polyp numbers that was significantly greater than those of the other groups. No significant difference in daily growth rate was observed among the control group and $\mathrm{S}, \mathrm{I}$, and $\mathrm{N}$ experimental groups. At present, limited studies have investigated the nutrition of corals, and corals are usually cultured as small polyps. Because of the small size of these segmented corals, the coral symbiotic algae cannot provide their own nutrition, and nutritional sources are often lacking under the conditions of artificial cultivation, affecting the growth and survival rates of the cultivated corals [23]. In one study, feeding Artemia salina nauplii to Galaxea fascicularis resulted in a high feeding rate but did not improve coral growth, which may have been related to the body composition of the A. salina [6]. In addition, the caliber of G. columna is only 50-100 $\mu \mathrm{m}$; hence, absorbing large feed organisms is impossible. Therefore, the size of a coral's caliber should be considered during selection of feed. Among the feeds used in the present study, S. cerevisiae, I. galbana tml, and N. oculata could all be microscopically observed in the corals' body cavities, and changes in body composition after feeding were also noted. We evaluated the nutrient absorption efficiency of corals on the basis of changes in body composition after providing G. columna with different feeds. The results suggested that the body composition of $G$. columna was affected by the feed given, with the experimental groups differing from 
the unfed control group. This may have been because different feeds contain different nutrients. Therefore, the results indicated that G. columna could increase some bodily nutrients through the intake of different feeds.

In addition to the feed quantity, the attractiveness of different feeds to G. columna may also affect the coral's feeding habits. $\mathrm{R}$ is a liquid feed with particles approximately $1 \mu \mathrm{m}$ in size. Thus, in addition to the composition of $\mathrm{R}$, which was more suitable for $G$. columna absorption, the size of the feed particles may have been relevant. G. columna fed daily with $\mathrm{R}$ at $5 \%$ or $10 \%$ of its body weight exhibited enhanced protease activity and protein content, but the zooxanthellae density and chlorophyll a concentration remained unaffected. Overall, the results indicate that $\mathrm{R}$ feeding at a daily quantity of $5 \%$ or $10 \%$ of the coral's body weight provides the optimal culture conditions for G. columna.

We analyzed the protein, lipid, and glucose content of the feed, as shown in Table 6. The protein content was highest in the R feed $(76.67 \pm 1.56 \mu \mathrm{g})$, I had the highest fat content, and $\mathrm{S}$ had the highest glucose content. G. columna body composition analysis indicated that $\mathrm{R}$ contained the most protein and the least carbohydrates. The protein content and growth efficiency were higher in the R-fed groups than in the other groups. Heterotrophic feeding is essential for corals to overcome any nutrient deficiency because nitrogen, phosphate, vitamins, and other trace elements are not synthesized through autotrophic feeding [6]. Raz-Bahat et al. (2017) [46] reported that the actinopharynx and mesenterial filaments are pivotal digestive systems in stony corals, and consideration of the digestive enzymes and chymotrypsinogen is crucial to elucidating the digestive system functionality of Stylophora pistillata. Therefore, corals can obtain nutrition through ingestion of food. Most stony corals can obtain $40-95 \%$ of base energy through the host [47,48]. Corals are also opportunistic heterotrophic feeders, exploiting several trophic pathways simultaneously [49]. Corals are known to range between the activities of a primary herbivore, producer, carnivore, detritivore, and consumer of dissolved nutrients [20,49]. These heterogeneous roles provide corals with myriad nutrients, such as phosphorus and alternative forms of lipids not provided by photosynthesis [20]. Our results suggest that feeding G. columna with R leads to considerable growth; by contrast, feeding it microalgae and yeast does not assist the growth of G. columna.

Yeast is a common live feed in aquaculture [50,51]. Different yeast cell walls have different components (e.g., $\beta$-glucan and oligosaccharide), and are commonly used as in fish diets or to replace fish meal [31,52-55]. Brewer's yeast can replace $50 \%$ of the fish meal content in Dicentrarchus labrax feed [31]. Feeding 25\% brewer's yeast can replace casein and improve the growth and feed conversion rate of rainbow trout (Oncorhynchus mykiss), whereas feeding 50\% will affect palatability and the feeding rate [56]. The present study's results indicate that using yeast as a feed for G. columna does not significantly increase growth, which may be related to the influence of yeast cell walls, lignocellulosic biomass, and the most abundant carbohydrate at the time of coral digestion [57,58]. Kim et al. (1998) [59] contended that tough cell walls are the main constraint on yeast's use as an aquaculture feed. Therefore, corals' ability to digest live yeast or absorb sugars may require further research.

According to the nutritional research on microalgae, I and $\mathrm{N}$ are rich in DHA and EPA, respectively [60,61]. Living microalgae constituents such as PUFAs, vitamins, sterols, and carbohydrates have key nutritional value [62]. Factors influencing the bioutilization of microalgae include its size, shape, digestibility, biochemical composition, enzyme activity, and toxins as well as the target organism's requirements for feeding [63]. Microalgae grown to the late logarithmic growth phase typically contain $10-20 \%$ lipid, $5-15 \%$ carbohydrate, and $30-40 \%$ protein [64]. Our results indicated no significant increase in the protein, lipid, or glucose content of G. columna specimens after 8 weeks of being fed I or S microalgae. The lipase and amylase content of the corals were also low, which may have led to an inability to metabolize fat and starch, thereby limiting the main cause of growth. In addition, the cell wall of microalgae generally comprises cellulose, which presents a challenge to bioaccessibility because of its low digestibility [61]. The microalgae I has cell diameter of 
approximately $3-5 \mu \mathrm{m}$, whereas the cell diameter of $\mathrm{N}$ is approximately $2-4 \mu \mathrm{m}$ [65]. The mouth diameter of G. columna is $50-100 \mu \mathrm{m}$; therefore, G. columna can comfortably ingest these two feeds. Corals are coelenterates-whatever food they cannot digest after initial ingestion is excreted from their mouths. We observed microalgae in the coral's body $1 \mathrm{~h}$ after eating, implying that the coral had swallowed the microalgae. Therefore, the results suggest that corals cannot digest microalgae after swallowing them, explaining the lack of significant increase in growth. Excessive feeding may cause excessive nutrients in the water and cause algae growth af-fects the growth of coral. Therefore, the feed selected in coral aquaculture should be one that can be quickly absorbed and does not pollute the water. During our study, the ammonia nitrogen and nitrite in the water were measured, and none of the experimental groups' water contained more than the standard levels.

The 24-h observation of G. columna body composition and digestive enzyme activity (Figure 3) indicated that the protein content of the coral was highest at 12:00, measuring $486 \pm 23.15 \mu \mathrm{g} / \mathrm{mg}$, and was significantly lower at 18:00, 00:00, and 06:00, measuring $324.13 \pm 21.03,321.49 \pm 19.46$, and $345.21 \pm 21.64 \mu \mathrm{g} / \mathrm{mg}$, respectively. The digestive enzyme protease activity also exhibited marked variation throughout the day; at 6:00, 12;00, 18:00, and 00:00, its registered activity was $153.25 \pm 20.32,385.67 \pm 16.48,285.15 \pm 17.12$, and $167.85 \pm 19.35 \mathrm{U} / \mathrm{mg}$ protein, respectively. The comparison of other aspects of digestive enzyme activity and protein content in the body (Figure 3 and Table 7.) indicated that low protein content occurs when digestive enzyme activity is low; when protein content is at its highest (12:00), the digestive enzyme activity is also its highest. Digestive enzyme activity was decreased at 18:00, at which point the protein content was also decreased, and finally when the digestive enzyme activity decreased to its daily low at 00:00, the body protein content was also at its lowest. Hence, the protein content increased to its highest level within $6 \mathrm{~h}$ of feeding, and the digestive enzyme activity decreased after $6 \mathrm{~h}$, suggesting that the digestion time was within $6 \mathrm{~h}$. According to Sebens and Koehl (1984) [66], digestion times vary among coral species. The digestion time of Alcyonium siderium fed zooplankton is approximately $4-6 \mathrm{~h}$. The hydrocoral Millepora complanata reportedly completes digestion of its prey in approximately $24 \mathrm{~h} \mathrm{[12].} \mathrm{G.} \mathrm{fascicularis} \mathrm{begins} \mathrm{to} \mathrm{digest} \mathrm{food} 10 \mathrm{~min}$ after ingestion and finishes within $180 \mathrm{~min}$ [6]. Studies have failed to thoroughly determine the key role of light or food in corals' physiological metabolism and growth. Light is a crucial factor in the physiology of coral symbiotic zooxanthellae and critical for the growth and maintenance of zooxanthellate coral in captivity $[67,68]$. Therefore, the digestion and absorption properties of corals change from day to day. When managing large-scale $G$. columna aquaculture, the establishment of definite feeding times is critical; we noted that the optimal feeding time for G. columna is between 6:00 and 12:00. At this time, higher protease activity aids digestion, metabolism, and absorption.

\section{Conclusions}

The coral aquaculture industry has gradually attracted attention, and feeding G. columna with the $\mathrm{R}(10)$ formulation can improve its growth and significantly improve its protein content compared with other feeds. The optimal feeding time is between 06:00 and 12:00, when the activity of digestive enzymes is highest and maximal benefit can obtained from the absorption of nutrients in ingested food. Our observations suggest that feeding with $\mathrm{R}$ can increase the number of coral polyps from 5 to 40 number over 2 months, accelerating the growth rate of G. columna. We expect our findings to be applied in coral farming enterprises. At present, the CITES-certified Taiwan Coral king Coral King Coral Farm (Kaohsiung, Taiwan) feeds corals with the $\mathrm{R}$ formulation between 6:00 and 12:00 daily, recording an annual output of up to 20,000 G. columna colonies, all housed in $150 \times 60 \times 30 \mathrm{~cm}$ tanks. 
Author Contributions: Conceptualization, D.-S.D., W.-T.S. and C.-H.P.; methodology, D.-S.D.; software, W.-T.S.; validation, D.-S.D. and W.-T.S.; formal analysis, D.-S.D.; investigation, D.-S.D.; resources, D.-S.D. and C.-H.P.; data curation, D.-S.D.; writing-original draft preparation, D.-S.D.; writing-review and editing, D.-S.D.; visualization, D.-S.D.; supervision, D.-S.D. and C.-H.P.; project administration, D.-S.D. All authors have read and agreed to the published version of the manuscript.

Funding: This research received no external funding.

Institutional Review Board Statement: All standard national and international ethical guidelines dealing with coral handling, challenge, and sampling were fully adopted by the research team (authors). The G. columna colonies used in this experiment were obtained from Taiwan Coral King coral farm (Kaohsiung, Taiwan), a CITES-certified legal coral farm (CITES No. FTS507W0153796).

Informed Consent Statement: Not applicable.

Data Availability Statement: Not applicable.

Acknowledgments: This research is grateful to Taiwan Coral King (Coral farm) aquarium company (Pingtung, Taiwan) for providing coral samples.

Conflicts of Interest: The authors declare no conflict of interest.

\section{References}

1. Connell, J.H. Some mechanisms producing structure in natural communities: A model and evidence from field experiments. Ecol. Evol. Communities 1975, 460-490.

2. Volkov, I.; Banavar, J.R.; Hubbell, S.P.; Maritan, A. Patterns of relative species abundance in rainforests and coral reefs. Nat. Cell Biol. 2007, 450, 45-49. [CrossRef] [PubMed]

3. Wabnitz, C.; Taylor, M.; Green, E.; Razak, T. From Ocean to Aquarium: The Global Trade in Marine Ornamental Species; UNEP World Conservation Monitoring Centre: Cambridge, UK, 2003.

4. Barton, J.; Willis, B.L.; Hutson, K.S. Coral propagation: A review of techniques for ornamental trade and reef restoration. Rev. Aquac. 2015, 9, 238-256. [CrossRef]

5. $\quad$ Osinga, R.; Schutter, M.; Griffioen, B.; Wijffels, R.H.; Verreth, J.; Shafir, S.; Henard, S.; Taruffi, M.; Gili, C.; Lavorano, S. The Biology and Economics of Coral Growth. Mar. Biotechnol. 2011, 13, 658-671. [CrossRef] [PubMed]

6. Hii, Y.-S.; Soo, C.L.; Liew, H.-C. Feeding of scleractinian coral, Galaxea fascicularis, on Artemia salina nauplii in captivity. Aquac. Int. 2008, 17, 363-376. [CrossRef]

7. Hodgson, G. A Global Assessment of Human Effects on Coral Reefs. Mar. Pollut. Bull. 1999, 38, 345-355. [CrossRef]

8. Crabbe, M.J.C.; Smith, D. Modelling variations in corallite morphology of Galaxea fascicularis coral colonies with depth and light on coastal fringing reefs in the Wakatobi Marine National Park (S.E. Sulawesi, Indonesia). Comput. Biol. Chem. 2006, 30, 155-159. [CrossRef]

9. Schlacher, T.A.; Stark, J.; Fischer, A.B. Evaluation of artificial light regimes and substrate types for aquaria propagation of the staghorn coral Acropora solitaryensis. Aquaculture 2007, 269, 278-289. [CrossRef]

10. Lasker, H. Comparison of the Particulate Feeding Abilities of Three Species of Gorgonian Soft Coral. Mar. Ecol. Prog. Ser. 1981, 5, 61-67. [CrossRef]

11. Ferrier, M.D. Net uptake of dissolved free amino acids by four scleractinian corals. Coral Reefs 1991, 10, 183-187. [CrossRef]

12. Lewis, J. Heterotrophy in corals: Zooplankton predation by the hydrocoral Millepora complanata. Mar. Ecol. Prog. Ser. 1992, 90, 251-256. [CrossRef]

13. Al-Moghrabi, S.; Allemand, D.; Couret, J.; Jaubert, J. Fatty acids of the scleractinian coral Galaxea fascicularis: Effect of light and feeding. J. Comp. Physiol. B 1995, 165, 183-192. [CrossRef]

14. Ferrier-Pagès, C.; Allemand, D.; Gattuso, J.-P.; Jaubert, J.; Rassoulzadegan, F. Microheterotrophy in the zooxanthellate coral Stylophora pistillata: Effects of light and ciliate density. Limnol. Oceanogr. 1998, 43, 1639-1648. [CrossRef]

15. Ferrier-Pagès, C.; Witting, J.; Tambutté, E.; Sebens, K.P. Effect of natural zooplankton feeding on the tissue and skeletal growth of the scleractinian coral Stylophora pistillata. Coral Reefs 2003, 22, 229-240. [CrossRef]

16. Picciano, M.; Ferrier-Pagès, C. Ingestion of pico- and nanoplankton by the Mediterranean red coral Corallium rubrum. Mar. Biol. 2007, 150, 773-782. [CrossRef]

17. Anthony, K.R.; Fabricius, K.E. Shifting roles of heterotrophy and autotrophy in coral energetics under varying turbidity. J. Exp. Mar. Biol. Ecol. 2000, 252, 221-253. [CrossRef]

18. Titlyanov, E.; Bil', K.; Fomina, I.; Titlyanova, T.; Leletkin, V.; Eden, N.; Malkin, A.; Dubinsky, Z. Effects of dissolved ammonium addition and host feeding with Artemia salina on photoacclimation of the hermatypic coral Stylophora pistillata. Mar. Biol. 2000, 137, 463-472. [CrossRef]

19. Mills, M.M.; Lipschultz, F.; Sebens, K.P. Particulate matter ingestion and associated nitrogen uptake by four species of scleractinian corals. Coral Reefs 2004, 23, 311-323. [CrossRef] 
20. Houlbrèque, F.; Meibom, A.; Stolarski, J.; Marrocchi, Y.; Ferrier-Pagès, C.; Domart-Coulon, I.; Dunbar, R.B.; Cuif, J.-P. Strontium-86 labeling experiments show spatially heterogeneous skeletal formation in the scleractinian coral Porites porites. Geophys. Res. Lett. 2009, 36. [CrossRef]

21. James, N.P. Diagenesis of scleractinian corals in the subaerial vadose environment. J. Paleontol. 1974, 785-799.

22. Goreau, T.F.; Goreau, N.I.; Yonge, C.M. Reef Corals: Autotrophs or Heterotrophs? Biol. Bull. 1971, 141, 247-260. [CrossRef]

23. Forsman, Z.H.; Rinkevich, B.; Hunter, C.L. Investigating fragment size for culturing reef-building corals (Porites lobata and $P$. compressa) in ex situ nurseries. Aquaculture 2006, 261, 89-97. [CrossRef]

24. Miller, M.W. Growth of a temperate coral:effects of temperature, light, depth, and heterotrophy. Mar. Ecol. Prog. Ser. 1995, 122, 217-225. [CrossRef]

25. Ferrier-Pagès, C.; Gattuso, J.P.; Dallot, S.; Jaubert, J. Effect of nutrient enrichment on growth and photosynthesis of the zooxanthellate coral Stylophora pistillata. Coral Reefs 2000, 19, 103-113. [CrossRef]

26. Titlyanov, E.; Titlyanova, T.; Yamazato, K.; van Woesik, R. Photo-acclimation of the hermatypic coral Stylophora pistillata while subjected to either starvation or food provisioning. J. Exp. Mar. Biol. Ecol. 2001, 257, 163-181. [CrossRef]

27. Grottoli, A.G. Effect of light and brine shrimp on skeletal $\delta 13 \mathrm{C}$ in the Hawaiian coral Porites compressa: A tank experiment. Geochim. et Cosmochim. Acta 2002, 66, 1955-1967. [CrossRef]

28. Houlbreèque, F.; Tambutteé, E.; Allemand, D.; Ferrier-Pagès, C. Interactions between zooplankton feeding, photosynthesis and skeletal growth in the scleractinian coral Stylophora pistillata. J. Exp. Biol. 2004, 207, 1461-1469. [CrossRef]

29. Davy, S.K.; Withers, K.J.; Hinde, R. Effects of host nutritional status and seasonality on the nitrogen status of zooxanthellae in the temperate coral Plesiastrea versipora (Lamarck). J. Exp. Mar. Biol. Ecol. 2006, 335, 256-265. [CrossRef]

30. Anderson, D.; Siwicki, A.; Rumsey, G. Injection or immersion delivery of selected immunostimulants to trout demonstrate enhancement of nonspecific defense mechanisms and protective immunity. In Diseases in Asian Aquaculture, Vol. 11, Fish Health Section Section; Sharff, M., Subasing, R.P., Arthur, J.R., Eds.; Asian Fisheries Society: Manila, Philippines, 1995; pp. $413-426$.

31. Oliva-Teles, A.; Gonçalves, P. Partial replacement of fishmeal by brewers yeast (Saccaromyces cerevisae) in diets for sea bass (Dicentrarchus labrax) juveniles. Aquaculture 2001, 202, 269-278. [CrossRef]

32. Bonaldo, R.M.; Hay, M.E. Seaweed-Coral Interactions: Variance in Seaweed Allelopathy, Coral Susceptibility, and Potential Effects on Coral Resilience. PLoS ONE 2014, 9, e85786. [CrossRef]

33. AOAC. Official Methods for the Analysis, 14th ed.; Association of Official Analytical Chemists, Arlington: Washington, DC, USA, 1984.

34. Bishop, M. Clinical Chemistry: Principles, Techniques, and Correlations; Jones \& Bartlett Publishers: Burlington, MA, USA, 2020.

35. Price, C.P.; Bossuyt, P.; Bruns, D.E. Tietz fundamentals of clinical chemistry. Medicine 1976, 3.

36. Conlan, J.A.; Humphrey, C.; Severati, A.; Francis, D. Influence of different feeding regimes on the survival, growth, and biochemical composition of Acropora coral recruits. PLoS ONE 2017, 12, e0188568. [CrossRef]

37. Conlan, J.A.; Bay, L.K.; Severati, A.; Humphrey, C.; Francis, D. Comparing the capacity of five different dietary treatments to optimise growth and nutritional composition in two scleractinian corals. PLoS ONE 2018, 13, e0207956. [CrossRef]

38. Conlan, J.; Humphrey, C.; Severati, A.; Parrish, C.; Francis, D. Elucidating an optimal diet for captive Acropora corals. Aquaculture 2019, 513, 734420. [CrossRef]

39. Rocha, R.J.; Pimentel, T.; Serôdio, J.; Rosa, R.; Calado, R. Comparative performance of light emitting plasma (LEP) and light emitting diode (LED) in ex situ aquaculture of scleractinian corals. Aquaculture 2013, 402-403, 38-45. [CrossRef]

40. Schutter, M.; van Velthoven, B.; Janse, M.; Osinga, R.; Janssen, M.; Wijffels, R.; Verreth, J. The effect of irradiance on long-term skeletal growth and net photosynthesis in Galaxea fascicularis under four light conditions. J. Exp. Mar. Biol. Ecol. 2008, 367, 75-80. [CrossRef]

41. Levy, O.; Dubinsky, Z.; Achituv, Y. Photobehavior of stony corals: Responses to light spectra and intensity. J. Exp. Biol. 2003, 206, 4041-4049. [CrossRef] [PubMed]

42. Jeffrey, S.T.; Humphrey, G.F. New spectrophotometric equations for determining chlorophylls a, b, c1 and c2 in higher plants, algae and natural phytoplankton. Biochem. Physiol. Pflanz. 1975, 167, 191-194. [CrossRef]

43. Sun, J.-Y.; Du, J.; Qian, L.-C.; Jing, M.-Y.; Weng, X.-Y. Distribution and characteristics of endogenous digestive enzymes in the red-eared slider turtle, Trachemys scripta elegans. Comp. Biochem. Physiol. Part A Mol. Integr. Physiol. 2007, 147, 1125-1129. [CrossRef] [PubMed]

44. Borlongan, I. Studies on the digestive lipases of milkfish, Chanos chanos. Aquaculture 1990, 89, 315-325. [CrossRef]

45. Bernfeld, P. Amylases, $\alpha$ and $\beta$. Methods Enzymol. 1955, 1, 149-158.

46. Raz-Bahat, M.; Douek, J.; Moiseeva, E.; Peters, E.C.; Rinkevich, B. The digestive system of the stony coral Stylophora pistillata. Cell Tissue Res. 2017, 368, 311-323. [CrossRef]

47. Titlyanov, E.A.; Titlyanova, T.V.; Van Woesik, R.; Yamazato, K. Acclimation of the Hermatypic Coral Stylophora pistillata to Bright Light. Russ. J. Mar. Biol. 2002, 28, S41-S47. [CrossRef]

48. Mieog, J.C.; Olsen, J.L.; Berkelmans, R.; Bleuler-Martinez, S.A.; Willis, B.L.; van Oppen, M.J. The roles and interactions of symbiont, host and environment in defining coral fitness. PLoS ONE 2009, 4, e6364. [CrossRef]

49. Nahon, S.; Richoux, N.B.; Kolasinski, J.; Desmalades, M.; Pages, C.F.; Lecellier, G.; Planes, S.; Lecellier, V.B. Spatial and Temporal Variations in Stable Carbon $\left(\delta^{13} \mathrm{C}\right)$ and Nitrogen $\left(\delta^{15} \mathrm{~N}\right)$ Isotopic Composition of Symbiotic Scleractinian Corals. PLoS ONE 2013, 8, e81247. [CrossRef] 
50. Brown, M.R.; Barrett, S.M.; Volkman, J.K.; Nearhos, S.P.; Nell, J.A.; Allan, G.L. Biochemical composition of new yeasts and bacteria evaluated as food for bivalve aquaculture. Aquaculture 1996, 143, 341-360. [CrossRef]

51. Abdel-Tawwab, M.; Abdel-Rahman, A.M.; Ismael, N.E. Evaluation of commercial live bakers' yeast, Saccharomyces cerevisiae as a growth and immunity promoter for Fry Nile tilapia, Oreochromis niloticus (L.) challenged in situ with Aeromonas hydrophila. Aquaculture 2008, 280, 185-189. [CrossRef]

52. Li, P.; Gatlin, D.M. Nucleotide nutrition in fish: Current knowledge and future applications. Aquaculture 2006, 251, 141-152. [CrossRef]

53. Gatesoupe, F. Live yeasts in the gut: Natural occurrence, dietary introduction, and their effects on fish health and development. Aquaculture 2007, 267, 20-30. [CrossRef]

54. Gopalakannan, A.; Arul, V. Enhancement of the innate immune system and disease-resistant activity in Cyprinus carpio by oral administration of $\beta$-glucan and whole cell yeast. Aquac. Res. 2009, 41, 884-892. [CrossRef]

55. Refstie, S.; Baeverfjord, G.; Seim, R.R.; Elvebø, O. Effects of dietary yeast cell wall $\beta$-glucans and MOS on performance, gut health, and salmon lice resistance in Atlantic salmon (Salmo salar) fed sunflower and soybean meal. Aquaculture 2010, 305, 109-116. [CrossRef]

56. Rumsey, G.; Hughes, S.G.; Smith, R.R.; Kinsella, J.E.; Shetty, K.J. Digestibility and energy values of intact, disrupted and extracts from brewer's dried yeast fed to rainbow trout (Oncorhynchus mykiss). Animal Feed Sci. Technol. 1991, 33, 185-193. [CrossRef]

57. Nasseri, A.; Rasoul-Ami, S.; Morowvat, M.H.; Ghasemi, Y. Single Cell Protein: Production and Process. Am. J. Food Technol. 2011, 6, 103-116. [CrossRef]

58. Rodrussamee, N.; Lertwattanasakul, N.; Hirata, K.; Limtong, S.; Kosaka, T.; Yamada, M. Growth and ethanol fermentation ability on hexose and pentose sugars and glucose effect under various conditions in thermotolerant yeast Kluyveromyces marxianus. Appl. Microbiol. Biotechnol. 2011, 90, 1573-1586. [CrossRef]

59. Kim, S.H.; Lin, D.P.; Matsumoto, S.; Kitazono, A.; Matsumoto, T. Fission Yeast Slp1: An Effector of the Mad2-Dependent Spindle Checkpoint. Science 1998, 279, 1045-1047. [CrossRef] [PubMed]

60. Olsen, A.I.; Olsen, Y.; Attramadal, Y.; Christie, K.; Birkbeck, T.H.; Skjermo, J.; Vadstein, O. Effects of short term feeding of microalgae on the bacterial flora associated with juvenile Artemia franciscana. Aquaculture 2000, 190, 11-25. [CrossRef]

61. Lemahieu, C.; Bruneel, C.; Dejonghe, C.; Buyse, J.; Foubert, I. The cell wall of autotrophic microalgae influences the enrichment of long chain omega-3 fatty acids in the egg. Algal Res. 2016, 16, 209-215. [CrossRef]

62. Dhont, J.; Van Stappen, G. Biology, Tank Production and Nutritional Value of Artemia. Live Feeds Marine Aquac. 2003, 65-121. [CrossRef]

63. Hemaiswarya, S.; Raja, R.; Kumar, R.R.; Ganesan, V.; Anbazhagan, C. Microalgae: A sustainable feed source for aquaculture. World J. Microbiol. Biotechnol. 2010, 27, 1737-1746. [CrossRef]

64. Fujii, K.; Nakashima, H.; Hashidzume, Y.; Uchiyama, T.; Mishiro, K.; Kadota, Y. Potential use of the astaxanthin-producing microalga, Monoraphidium sp. GK12, as a functional aquafeed for prawns. Environ. Boil. Fishes 2009, 22, 363-369. [CrossRef]

65. Roselet, F.F.G.; Escalonamento do Cultivo e da flo Culação da Microalga Marinha Nannochloropsis Oculata. Repositorio Institucional da Universidade Federal do Rio Grande. 2015. Available online: http:/ / repositorio.furg.br/handle/1/8532 (In Spanish) (accessed on 1 September 2021).

66. Sebens, K.P.; Koehl, M.A.R. Predation on zooplankton by the benthic anthozoans Alcyonium siderium (Alcyonacea) and Metridium senile (Actiniaria) in the New England subtidal. Mar. Biol. 1984, 81, 255-271. [CrossRef]

67. Muscatine, L. The role of symbiotic algae in carbon and energy flux in reef corals. Coral Reefs 1990, $25,75-87$.

68. Osinga, R.; Janssen, M.; Janse, M. The role of light in coral physiology and its implications for coral husbandry. Adv. Coral Husb. Public Aquar. 2008, 2, 173-183. 